\title{
REVIEW
}

\section{Roan antelope Hippotragus equinus in Africa: a review of abundance, threats and ecology}

\author{
Carl P. HAVEMANN \\ Mammal Research Institute, Department of Zoology and Entomology, University of Pretoria, Private Bag X20, Hatfield \\ 0028, South Africa. E-mail: cphavemann@zoology.up.ac.za
}

Tarryn A. RETIEF

Department of Zoology and Entomology, University of Pretoria, Private Bag X20, Hatfield 0028, South Africa. E-mail: taretief@zoology.up.ac.za

Cheryl A. TOSH

Mammal Research Institute, Department of Zoology and Entomology, University of Pretoria, Private Bag X20, Hatfield 0028, South Africa. E-mail: catosh@zoology.up.ac.za

P. J. Nico DE BRUYN*

Mammal Research Institute, Department of Zoology and Entomology, University of Pretoria, Private Bag X20, Hatfield 0028, South Africa. E-mail: pjndebruyn@zoology.up.ac.za

${ }^{*}$ Correspondence author

\section{ABSTRACT}

1. The roan antelope Hippotragus equinus, Africa's second largest antelope species, is widely distributed throughout Africa. Many populations are isolated, occur at low densities, and are declining. The species' interactions with and adaptations to the diverse environmental conditions throughout its geographic range remain largely unknown. Most studies have taken place in southern Africa, near the range limit for the species; few studies have been conducted on the historically large Central and West African populations.

2. We reviewed available published and accessible unpublished data related to the ecology of roan antelope. We aim to: (1) review available taxonomic, abundance, distribution and population trend data; (2) describe the threats faced by the roan 
antelope, and establish whether sufficient data exist to describe their ecological requirements; and (3) highlight the relevance of conserving this species throughout Africa and suggest where research on survival requirements should be focussed.

3. Roan antelope populations throughout Africa are declining due to natural and anthropogenic threats. Methodological irregularities result in uncertainty and noncomparable population data between studies. Large gaps exist in our knowledge of roan antelope diet and regional movements. Information on the population genetics of roan antelope is needed, in order to assess the connectedness of different populations.

4. Data deficiency severely impedes our ability to employ powerful analytical methods aimed at understanding and predicting population persistence and viability, and to model envisaged threats from impending climate change. A unified approach to fundamental ecological research is required to inform the conservation and management of large rare mammalian ungulates such as the roan antelope in Africa.

Keywords: abundance, artiodactyla, distribution, roan antelope, ungulate ecology

\section{INTRODUCTION}

The African savanna biome supports the highest diversity of ungulate species (du Toit \& Cumming 1999), but large mammal populations in many of Africa's protected areas (PAs) are declining (Craigie et al. 2010). Globally, wildlife populations are threatened by human-induced environmental degradation and climate change (Thuiller et al. 2006). The sensitivity of wildlife populations to change at large spatial scales (Thuiller et al. 2006) can only be quantified using knowledge of individual populations' responses to environmental changes at regional scales. The aesthetic, scientific and economic value of large African herbivore populations (East 1999, Hanks 2001) provides impetus for their conservation (Gordon et al. 2004). They provide an important source of revenue through sports hunting and ecotourism. Many charismatic herbivore species are flagship species for conservation programmes, and several are currently threatened by high levels of poaching (e.g. Lopes 2015). Large herbivores play a keystone role in the structure, composition and functioning of many ecosystems, as a result of their feeding and movement patterns (e.g. Waller \& Alverson 1997). The socio-political climate in Africa can hamper both the conservation of and research on African ungulates.

The general ecology and role of the roan antelope Hippotragus equinus in the environment throughout Africa is not well understood. In this review, we make a first attempt to assess our current know ledge 
of the roan antelope in Africa, in order to stimulate directed and effective future research. We aim to: (1) review available taxonomic, abundance, distribution and population trend data; (2) describe the threats faced by the roan antelope, and establish whether sufficient data exist to describe their ecological requirements; and (3) highlight the relevance of conserving this species throughout Africa and suggest where research on survival requirements should be focussed.

\section{METHODS}

Our literature was obtained using Google Scholar and Scopus database searches with the following keywords: abundance, distribution, ecology, home range, habitat use, foraging, and threats, in combination with either 'roan antelope' or 'Hippotragus equinus'. The following information was extracted from each paper: (1) abundance estimates and the methodology used to obtain the estimate; (2) species distribution; (3) any results regarding general ecology (e.g. home range, habitat utilization, foraging, diet) obtained from reliable field methods; and (4) any mention of threats faced by this species and possible solutions to mitigate these threats. Our search covered the years 1960 to 2014, and data from 65 publications were included in the review.

\section{RESULTS AND DISCUSSION}

\section{Taxonomy}

The roan antelope is Africa's second largest antelope species (Martin 2003). It was first classified by Desmarest in 1804 (Harris 1852); several classifications followed thereafter (see Barrie 2009, Kimanzi 2011). Ansell (1971) recognized and described six subspecies of Hippotragus equinus: equinus, cottoni, langheldi, bakeri, charicus and koba (Figure 1) based on morphological rather than genetic characteristics (Alpers et al. 2004), although the validity and geographic limits of these subspecies are questionable (Matthee \& Robinson 1999). Outdated descriptions of subspecies (all predating 1928) that relied on small sample sizes, no genetic testing, and a poor geographical representation (Matthee \& Robinson 1999) have given rise to uncertainties about the subspecific status of roan antelope. Based on these shortcomings, recognizing any subspecies of roan antelope may be invalid (Martin 2003). Only two genetic studies (Matthee \& Robinson 1999, Alpers et al. 2004) provide partial support for differentiating between some of the putative subspecies. Matthee and Robinson (1999) found four of the six subspecies of roan antelope (equinus, koba, cottoni, and langheldi) to be geographically distinct based on mitochondrial DNA analysis, but their study suffered from several flaws including a poor sampling regime and small sample sizes. A unique West African population (Benin, Senegal, and Ghana), corresponding to Hippotragus equinus koba was proposed by Alpers et al. (2004) based on evidence from mitochondrial DNA together with 
microsatellite genotyping. Less support was found for subspecies from the rest of Africa, particularly in the southern populations.

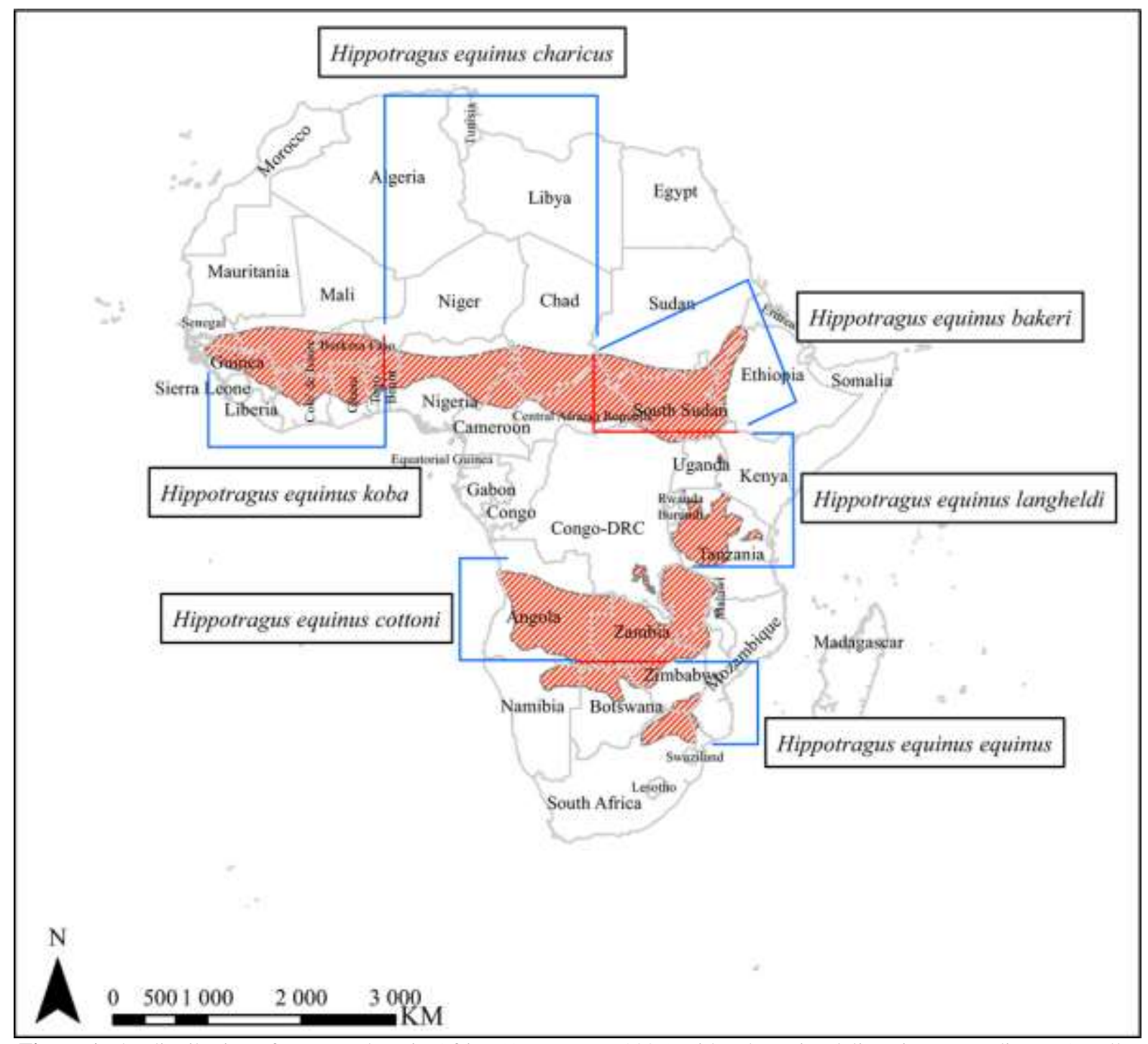

Figure 1 The distribution of roan antelope in Africa (Anonymous 2006) with subspecies delineations according to Ansell 1971.

\section{Distribution and abundance}

Roan antelope are endemic to Africa and are found throughout most parts of the northern and southern savannas. Although widely distributed in Africa (Beudels et al. 1992, Dörgeloh et al. 1996; Figure 2), their local distribution is often patchy and discontinuous (Skinner \& Smithers 1990) and they occur at low densities (Estes 1992). Abundance estimates of roan antelope are speculative; numbers were estimated to be between 39000 and 76000 individuals in 1998 (East 1999). In 1998, one-third of roan antelope populations were stable or increasing, the rest were declining (East 1999). Current population trends throughout Africa are largely unknown and numbers may be lower than 18 years ago. In 1996, the roan antelope was listed in the International Union for Conservation of Nature's (IUCN) Red List as 'Threatened' (Kimanzi \& Wanyingi 2014). The 2008 IUCN assessment 
advised that there was insufficient evidence for a 'Near Threatened' or 'Threatened' categorisation, and so the roan antelope was classed as a species of 'Least Concern' (Mallon \& Hoffmann 2008) at a continental scale. The low numbers and the isolation of metapopulations of roan antelope make this a species of national concern in many countries (Martin 2003).

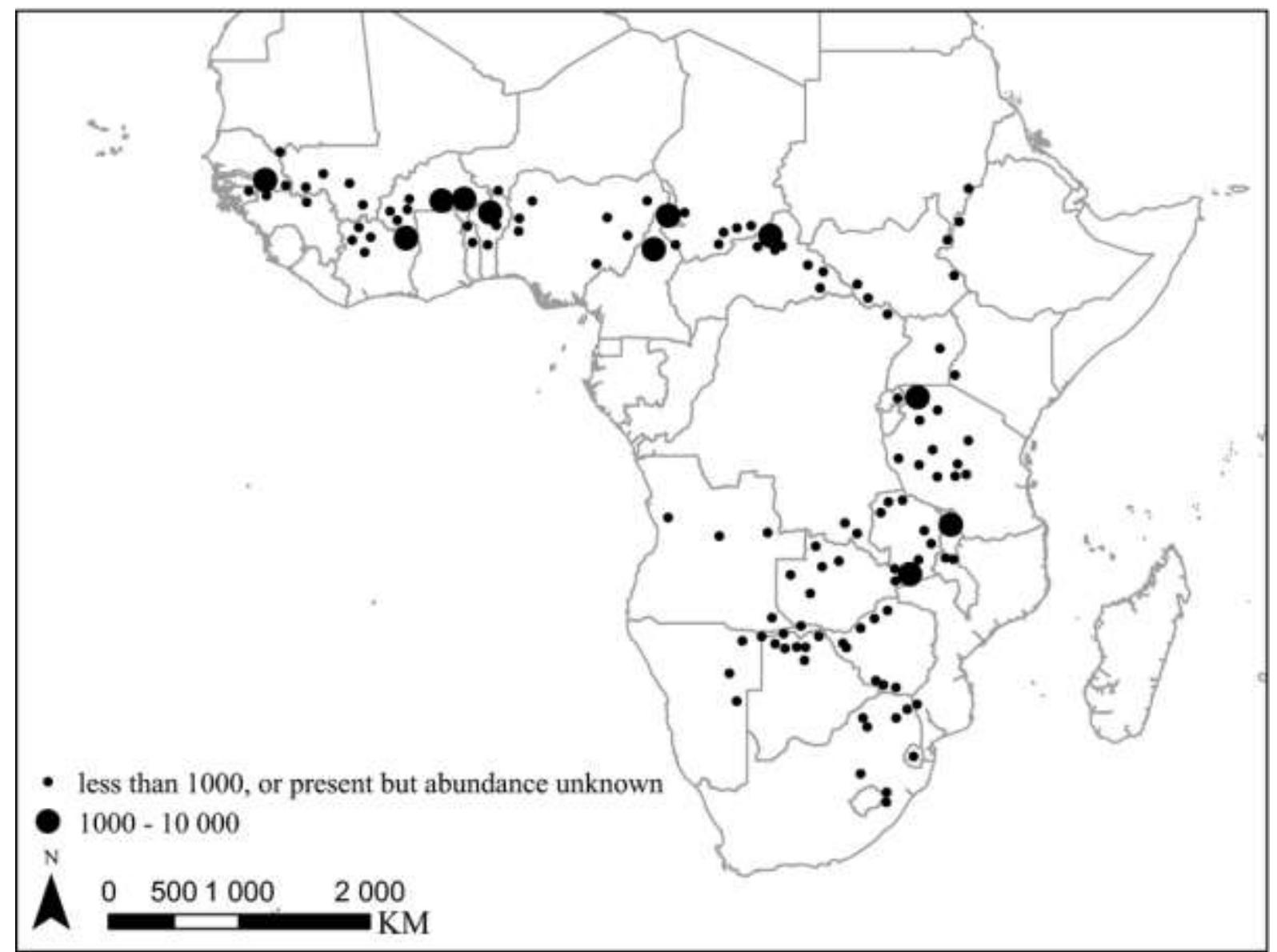

Figure 2 Distribution and relative abundance of roan antelope Hippotragus equinus in sub-Saharan Africa (East 1999).

Between 1960 and 2015, 91 studies were focused on the distribution and abundance of large mammals, including roan antelope, in Africa. Most of these studies (65\%) were conducted prior to 2000 (Figure 3). Varied field methods have been employed for abundance estimation in different areas over time (Figure 4). Recent studies (since 2000) were conducted in only 15 of the 31 (48\%) countries where roan antelope occur. Regional factors play an important role in roan antelope ecology in Africa, and we assess regional population trends and conservation issues for roan antelope. 


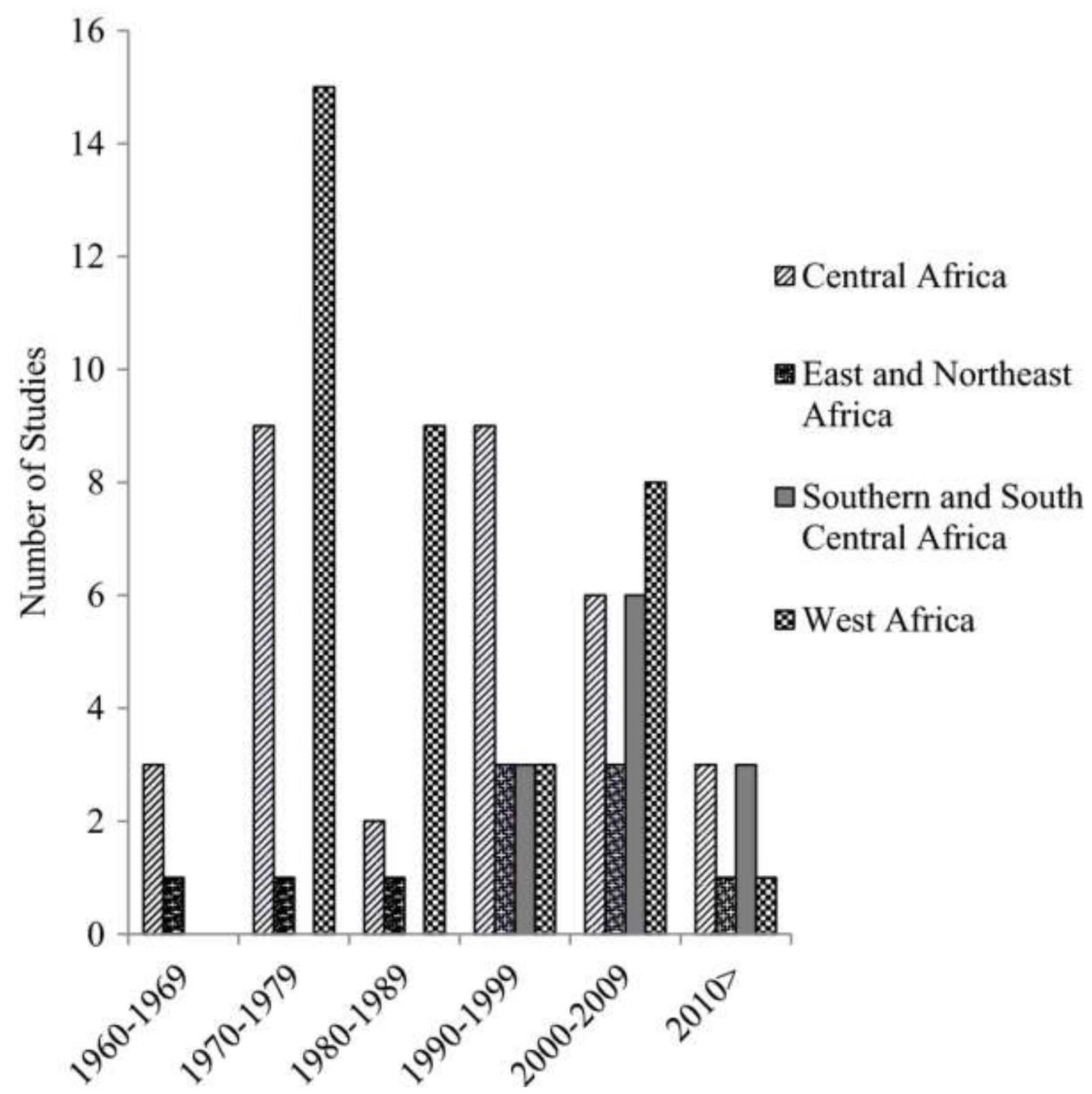

Figure 3 The geographical spread of 91 studies of large mammals (including published and unpublished sources), which included roan antelope abundance/density estimates, conducted between 1960 and 2015 in Africa. 


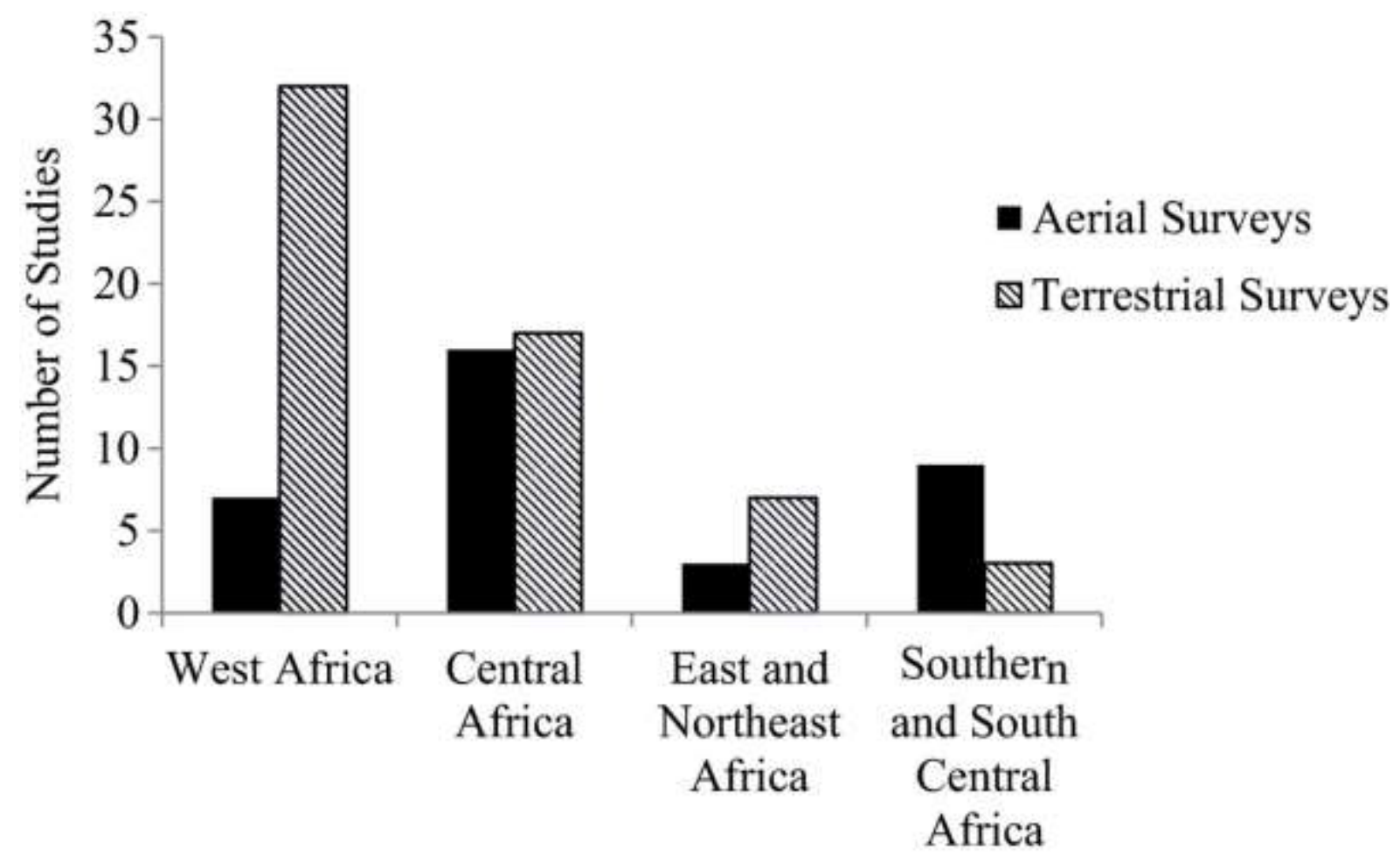

Figure 4 Number of aerial surveys and terrestrial surveys (from published and unpublished sources) used to calculate densities of large mammals, including roan antelope, in Africa between 1960 and 2015. Total N=90.

\section{SOUTHERN AND SOUTH-CENTRAL AFRICA}

Roan antelope occur in Angola, Botswana, Malawi, Mozambique, Namibia, South Africa, Swaziland, Zambia and Zimbabwe, 9 of the 10 countries in southern and south-central Africa (excluding the islands of Madagascar, Mauritius and Seychelles; country divisions based on East 1999). Roan antelope are considered rare and endangered in the southern African sub-region (Martin 2003). Much of the roan antelope population in the sub-region resides in PAs, conservation concession areas and privately owned game farms in small populations (<100 individuals; Dörgeloh et al. 1996). The populations are intensively managed and well monitored throughout the sub-region.

Earlier estimates suggested that 1200 roan antelope occur in South Africa; only 300 were considered to be wild individuals, $88 \%$ were residing in small populations ( $<100$ individuals) on private lands, and the remainder were in PAs (East 1999). The dramatic increase in roan antelope farming in South Africa (there were estimated to be 3500 individuals on farms in 2013; Bezuidenhout 2013) may have changed these numbers in recent years (PJN de Bruyn pers. obs.).

The popularity of the roan antelope as a game ranch animal (Alpers et al. 2004) has led to its largescale movement into Namibia (Martin 2003). Roan antelope were introduced to the Etosha National Park in 1970 and to the Waterberg Plateau Park in 1975 (Martin 2003). Most of Namibia receives less than $400 \mathrm{~mm}$ of rain annually, too little for the survival of roan antelope (Martin 2003), and thus falls 
outside the natural range of the species. Namibian roan antelope populations have shown a stepwise decline in numbers since 1980 (Grant \& van Der Walt 2000, Martin 2003). There were approximately 800 roan antelope in Namibia prior to 2003 (50\% on commercial farms, 32\% in state PAs [excluding Caprivi], 12\% in conservancies, 6\% in West and East Caprivi; Martin 2003). According to the Ministry of the Environment and Tourism (Anonymous 2003), approximately $50000 \mathrm{~km}^{2}$ of land in north-eastern Namibia is suitable for roan antelope habitation. Kaudum Game Reserve in this sector supports roan antelope in seemingly large numbers (Martin 2003), but this population has not been counted in recent years.

Roan antelope in Botswana have decreased from 1357 individuals (East 1999, Martin 2003) to between 615 and 710 individuals in recent years (Matthys et al. 2010, Chase 2011, Anonymous 2012). Roan antelope are restricted to the north-east of the country in the Ngamiland and Chobe district (Anonymous 2012); a few isolated populations occur in the Okavango Delta.

Roan antelope numbers in Zimbabwe have declined from 1000 individuals in the early 1980s (Martin 2003) to between 300 and 500 individuals in 1998 (East 1999). Most of the population (200-300 individuals) probably occurs within the Hwange-Matetsi-Gwaai region of north-western Matabeleland (Grant \& Van der Walt 2000, Martin 2003), although current numbers are unknown. Political instability resulting in poor socio-economic conditions in Zimbabwe during the past 13 years has increased poaching in general (including poaching of roan antelope), and has contributed to a likely reduction in roan antelope numbers. Previously large populations of roan antelope in Angola and Mozambique have been reduced or entirely eradicated in many parts due to long-lasting civil wars (East 1999). Twenty-five roan antelope were re-introduced to the Limpopo National Park (Mozambique) in 2005, captured in the Nwaswitshumbe enclosure of the adjoining Kruger National Park (KNP; South Africa; V. Macandza pers. comm.). However, roan antelope were not observed in the 2010 or the 2013 aerial census of the Limpopo National Park, suggesting that roan antelope either declined rapidly or dispersed in the park (Stephenson 2013). At the last assessment, a large roan antelope population existed in Zambian and Malawian national parks and game management areas (Zambia >5000; Malawi >1500 individuals; East 1999). Roan antelope, historically extinct in Swaziland, were successfully reintroduced to the Mlilwane Game Reserve in 2003, and there are currently more than 30 individuals (www.backtoafrica.co.za).

\section{EAST AND NORTHEAST AFRICA}

At the last assessment, roan antelope occurred in Ethiopia, Kenya, Rwanda, Sudan, Tanzania and Uganda (East 1999). Roan antelope are extinct in Eritrea and Burundi (East 1999) and locally extinct in the Serengeti National Park, Tanzania and the Masai Mara National Reserve, Kenya (Kimanzi \& Wanyingi 2014). Fewer than 50 roan antelope remain in the Ruma National Park in Kenya; these 
animals constitute the last remaining population in Kenya (Kimanzi \& Wanyingi 2014). Roan antelope are consequently considered to be critically endangered in Kenya (Allsopp 1979, Kimanzi \& Wanyingi 2014). More than 4000 individuals were thought to occur in Tanzania in 1998 (East 1999), although recent declines of up to 50\% (from 1980 to 2000) have been documented in aerial surveyed zones (Stoner et al. 2006, 2007). Approximately 1300 individuals have been counted in the Katavi Rukwa ecosystem in Tanzania (Martin \& Caro 2012). Roan antelope populations have decreased in Akagera National Park, Rwanda, from 144 to between 35 and 50 individuals (Beudels et al. 1992, Bryan Havemann, pers. comm.). Roan populations were also decreasing in Sudan ( 760 individuals in one of the 26 PAs), Ethiopia and Uganda prior to 1998 (East 1999), and no recent estimates exist for these countries.

\section{CENTRAL AFRICA}

Roan antelope occur in Cameroon, the Central African Republic, Chad and the Democratic Republic of Congo (East 1999). More than 6000 individuals were counted in Cameroon prior to 1998 (East 1999). In addition to occurring on private land, roan antelope are only found in two of the nine national parks, namely Waza National Park and Bouba Ndjida National Park, although the most recent estimates of numbers in Bouba Ndjida National Park pre-date 1977 (Van Lavieren \& Esser 1979). Roan antelope have declined in the Waza National Park from more than 4000 individuals in the early 1960s to approximately 315 individuals at the latest count (Scholte et al. 2007, Foguekem et al. 2010). Their numbers dropped by $69 \%$ between 2005 and 2010, from a large population of 4000 individuals to approximately 1065 individuals in the Central African Republic (Bouché et al. 2009, 2012). The current status of roan antelope in the Democratic Republic of Congo is unknown, and they were last considered rare and uncommon (East 1999). In 1998, Chad was estimated to have more than 1500 individuals (East 1999), although no recent estimates exist.

\section{WEST AFRICA}

West African roan antelope populations appear to be locally abundant (Beudels et al. 1992) or even thriving (Codron et al. 2009) despite a paucity of data (nine studies of abundance since 1999) and uncertainty surrounding population estimates. East's (1999) assessment showed that roan antelope occur in Benin, Burkina Faso, Ghana, Guinea-Bissau, Guinea, Ivory Coast, Mali, Mauritania, Niger, Nigeria, Senegal and Togo. During 2006, 775 individual roan antelope were counted in Nigeria's Yankari ecosystem (Omondi et al. 2006) during aerial counts, while 452 individuals were estimated to be in the same area from road side counts between January and July 2008 (Mohammed et al. 2010). Burkina Faso was believed to hold the largest population of roan antelope in Africa, estimated at more than 7000 individuals in 1998 (East 1999). Between 4685 and 5332 individuals were recently counted on a single game ranch (Nazinga Game Ranch) in Burkina Faso (Marchal et al. 2012). In the Comoé National Park, Ivory Coast, roan antelope numbers have dropped by $72 \%$, from $\sim 1800$ individuals 
(1978) to 500 individuals (1998; Fischer \& Linsenmair 2001). The actual population estimate may be higher ( 1300 individuals) if all conservation areas are included in the estimate (East 1999). The distribution of roan antelope in Ghana has decreased from being present in five PAs to three PAs since 1971 (Brashares et al. 2001). Roan antelope populations elsewhere in West Africa are also thought to be declining, in Mauritania (abundance unknown), Mali ( $<1500$ individuals prior to 1998), Niger ( $<700$ individuals prior to 1998), Senegal ( $<2400$ individuals prior to 1998), Guinea-Bissau (abundance unknown), Guinea (abundance unknown), Togo (abundance unknown) and Benin $(<2500$ individuals prior to 1998; East 1999, Sinsin et al. 2002, Omondi et al. 2006, Scholte et al. 2007), despite a lack of research and baseline knowledge. Data-poor countries are often characterised by difficult socio-economic conditions which affect resources available for research. Difficult socioeconomic conditions put pressure on local wildlife populations, creating challenges for conservation.

\section{Threats to populations}

By 1998, roan antelope numbers had declined in 25 of the $31(81 \%)$ countries where they were known to occur (East 1999). Reasons for these declines varied between regions and subpopulations. In southern Africa, roan antelope numbers in the KNP dropped drastically from 450 individuals in 1986 to less than 45 individuals in 1993 (Harrington et al. 1999). Roan antelope numbers decreased due to increased predation by lions Panthera leo following the influx of zebra Equus quagga (formerly Equus burchellii) and wildebeest Connochaetes taurinus attracted to the newly created artificial water-points in traditionally semi-arid areas in the KNP (Harrington et al. 1999). The provision of artificial water-points within the roan antelope's range also resulted in extensive habitat degradation and competition with other herbivores (Harrington et al. 1999, Grant \& Van der Walt 2000, Grant et al. 2002). The closing of artificial water-points in the northern parts of the KNP have not led to recovery in roan antelope populations. Sable antelope Hippotragus niger numbers have also declined drastically in the KNP, due to the same causal factors (Owen-Smith et al. 2012). The continued inability of sable antelope populations to recover may be due to an Allee affect, where reduced herd vigilance causes increased juvenile mortality from predation and declining population numbers (Owen-Smith et al. 2012). A similar Allee effect may be causal in the roan antelope population's inability to recover. Anthrax outbreaks also continue to have negative effects on roan antelope populations in South Africa and Zimbabwe (see Clegg et al. 2007). The Malilangwe Wildlife Reserve in Zimbabwe lost $42 \%$ of its roan antelope population in 2004 (Clegg et al. 2007) and the KNP lost 45 individuals in 2012 in the Capricorn Breeding Enclosure (G. Smit unpublished data). Aerial vaccination and mass capture and immunisation have been implemented to protect this antelope species from stochastic disease outbreaks (Clegg et al. 2007).

Threats to roan antelope populations in the rest of Africa have not been comprehensively assessed in recent times (Poché 1974, Allsopp 1979, Beudels et al. 1992, Martin 2003, Kimanzi et al. 2014, 
Kimanzi \& Wanyingi 2014). Threats faced by various subpopulations of roan antelope, the majority of which were documented in southern Africa, include predation (McLoughlin \& Owen-Smith 2003), poaching (Kimanzi et al. 2015), habitat loss and deterioration, competition from other grazers and livestock, diseases, human settlement, the erection of veterinarian fences and agricultural encroachment, low rainfall, extreme droughts, fires, floods and inbreeding (Grant \& Van der Walt 2000, Martin 2003, Waltert et al. 2009, Kimanzi \& Wanyingi 2014). The effects of these pressures on roan antelope survival appears to be locally variable, and roan antelope populations seem to be declining at an unprecedented rate (Kimanzi \& Wanyingi 2014). Political instability (due to various factors, from government corruption to civil wars) is common in many countries where roan antelope are thought to be abundant. Political instability has direct effects on animal populations and is an impediment to conservation and research in these countries (East 1999, di Marco et al. 2014). Armed conflict (occurring in 50\% of sub-Saharan African countries during the past three decades), coupled with weak political commitment to conservation; corruption; lack of resources; poor enforcement of conservation laws; uncontrolled exploitation of resources; significant increase in human populations; and illegal poaching will continue to have a negative influence on the survival of biodiversity in Africa as a whole.

The human population in Africa has increased at a rate of $2.6 \%$ per annum over the last 10 years; it is currently estimated at 1.1 billion (Anonymous 2015)). In Africa, the human population is expected to double in the next 30 years (UNPD)). Much of this burgeoning population exists in isolated rural conditions and with little access to resources from larger economic centres (Linard et al. 2012). In response to the challenges posed by increasing human populations, there has been a $500 \%$ increase in PAs over the last three decades (Wittemyer et al. 2008). Despite this large increase in conservation effort, PAs have not been effective everywhere (Craigie et al. 2010, van Wilgen \& Biggs 2011). Throughout Africa, numbers of large mammals have declined by 59\% since 1970 (Craigie et al. 2010). High human densities around most of Africa's PAs result in increased human-wildlife conflict (Wittemyer et al. 2008). Large declines in both the size and diversity of ungulate populations within PAs may result from encroaching human settlements (Fynn \& Bonyongo 2011) and increasing isolation of PAs (Newmark 2008). Approximately $60 \%$ of roan antelope populations were confined to PAs by 1998 (East 1999), so increasing isolation of and population declines in roan antelope are major concerns.

Ineffective management and inadequate protection are current challenges for large mammal conservation in many PAs in Africa (Foguekem et al. 2010). Poaching, particularly for the bushmeat trade in West and Central Africa, contributes more to national economies than commercial logging and agriculture combined (Fischer \& Linsenmair 2001, Bouché et al. 2012). Uncontrolled poaching for bushmeat is the most important factor impacting large mammal densities in West Africa (Craigie 
et al. 2010). Roan antelope are a targeted source of meat in the Ivory Coast (Fischer 2004), and incidental poaching with snares is the primary cause of roan antelope decline in Ruma National Park, Kenya (Kimanzi et al. 2014).

Large gaps exist in our understanding of threats faced by roan antelope populations in Africa. In order to conserve the species effectively, we need to fill these data gaps and find ways to mitigate threats.

\section{Ecology, home ranges and vegetation preferences}

The ecology of the roan antelope has primarily been studied in South Africa (see Table 1), at the southern edge of its continental geographical range (Figure 5; Grant \& Van der Walt 2000, Kröger \& Rogers 2005). Few studies document the ecology of this species in its prime habitat $(60 \%$ of published research comes from the rest of Africa), which also coincides with large rural human settlements (Linard et al. 2012). The lack of research in these areas, where pressure from rural communities is presumably increased, is concerning (Wittemyer et al. 2008). Research on the roan antelope has been focussed on habitat utilization (32\%), home range (5\%) and foraging ecology

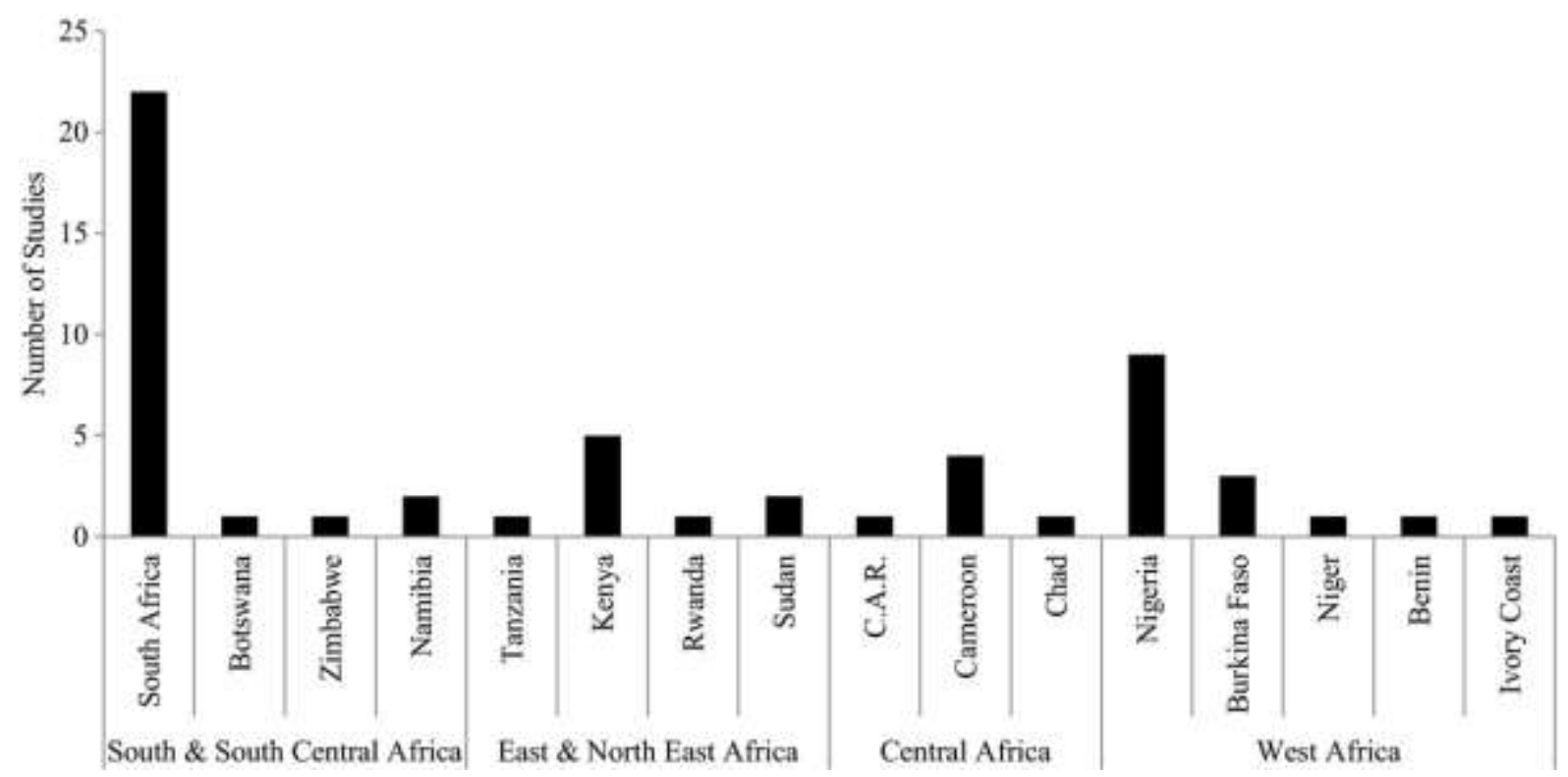

Figure 5 Numbers of ecological studies conducted in Africa between 1960 and 2015 in which the roan antelope was mentioned in the title $(\mathrm{N}=32)$ and abstract $(\mathrm{N}=24)$.

(27\%) in South Africa (see Figure 6 and Table 1). Home range, habitat use and foraging ecology have also been studied in Benin, Botswana, Burkino Faso, Kenya, Namibia and Nigeria; these countries represent only $23 \%$ of the species' natural geographical range. Habitat utilization has been briefly mentioned in studies conducted in the Ivory Coast (Geerling \& Bokdam 1973), Tanzania (Caro 1999, Walter et al. 2009), Nigeria (Afolayan \& Ajayi 1980, Ajayi et al. 1981), and Cameroon (Van Lavieren \& Esser 1979, Stark 1986, Tchamba \& Elkan 1995, Scholte et al. 2007, Foguekem et al. 


\begin{tabular}{|c|c|c|c|c|c|c|c|c|c|c|c|c|}
\hline Author & Region & Country & Abu. & Dist. & H.R. & H.U. & Diet & Beh. & Pop. Growth & Pop. Trend & Threats/ Dec. & Econ. Value \\
\hline Poché (1974) & $\mathrm{W}$ & Benin, Burkina Faso, Niger & $\mathbf{x}$ & & & & & & & & & \\
\hline Schuette et al.(1998) & $\mathrm{W}$ & Burkina Faso & & & & & $\mathbf{X}$ & & & & & \\
\hline Aremu (2004) & $\mathrm{W}$ & Nigeria & $\mathbf{X}$ & $\mathbf{X}$ & & $\mathbf{X}$ & $\mathbf{X}$ & & & & & \\
\hline Omondi et al. (2006) & $\mathrm{W}$ & Nigeria & $\mathbf{X}$ & & & & & & & & & \\
\hline Tyowua et al. (2010) & $\mathrm{W}$ & Nigeria & & & & $\mathbf{X}$ & & & & & & \\
\hline Tyowua et al. (2012a) & $\mathrm{W}$ & Nigeria & & & & $\mathbf{X}$ & & & & & & \\
\hline Tyowua et al. (2012b) & $\mathrm{W}$ & Nigeria & & & & $\mathbf{X}$ & & & & & & \\
\hline Tyowua et al. (2012c) & $\mathrm{W}$ & Nigeria & & & & & & & & $\mathrm{X}$ & & \\
\hline Tyowua et al. (2013) & $\mathrm{W}$ & Nigeria & & & & & $\mathbf{X}$ & & & & & \\
\hline Sekulic (1978) & $N \& N E$ & Kenya & $\mathbf{X}$ & & & & & $\mathbf{X}$ & & & & \\
\hline Allsopp (1979) & $N \& N E$ & Kenya & $\mathbf{X}$ & $\mathbf{X}$ & $\mathbf{X}$ & $\mathbf{X}$ & & $\mathbf{X}$ & & & $\mathbf{X}$ & \\
\hline Beudels et al. (1992) & $N \& N E$ & Rwanda & $\mathbf{X}$ & $\mathbf{X}$ & & & & & $\mathbf{X}$ & & $\mathbf{X}$ & \\
\hline Kimanzi (2011) (Thesis) & $N \& N E$ & Kenya & $\mathbf{X}$ & $\mathbf{X}$ & $\mathbf{X}$ & $\mathbf{X}$ & & & $\mathbf{X}$ & $\mathbf{X}$ & $\mathbf{X}$ & \\
\hline Kimanzi et al. (2014) & $N \& N E$ & Kenya & & & & $\mathbf{X}$ & & & & & & \\
\hline Kimanzi et al. (2015) & $N \& N E$ & Kenya & & & & & & & & & $\mathbf{X}$ & \\
\hline Kimanzi \& Wanyingi (2014) & $N \& N E$ & Kenya & & & & & & & & & $\mathbf{X}$ & \\
\hline Joubert (1970) (Thesis) & $\mathrm{S} \& \mathrm{SC}$ & R.S.A. & & $\mathbf{X}$ & & & & $\mathbf{X}$ & & & & \\
\hline Joubert (1976) (Thesis) & $\mathrm{S} \& \mathrm{SC}$ & R.S.A. & $\mathbf{X}$ & $\mathbf{X}$ & $\mathbf{X}$ & $\mathbf{X}$ & $\mathbf{X}$ & $\mathbf{X}$ & & & $\mathbf{X}$ & \\
\hline Wilson (1975) (Thesis) & $S \& S C$ & R.S.A. & & & & & & & & & $\mathbf{X}$ & \\
\hline Wilson \& Hirst (1977) & $S \& S C$ & R.S.A. & & $\mathbf{X}$ & $\mathbf{X}$ & $\mathbf{X}$ & $\mathbf{X}$ & $\mathbf{X}$ & & & $\mathbf{X}$ & \\
\hline Kiley-Worthington (1978) & $S \& S C$ & R.S.A. & & & & & & $\mathbf{X}$ & & & & \\
\hline Erb (1993) (Thesis) & $\mathrm{S} \& \mathrm{SC}$ & Namibia & & $\mathbf{X}$ & $\mathbf{X}$ & $\mathbf{X}$ & $\mathbf{X}$ & & & & & \\
\hline Heitkonig (1994) (Thesis) & $S \& S C$ & R.S.A. & & & & $\mathbf{X}$ & $\mathbf{X}$ & & & & & \\
\hline Harrington (1996) (Thesis) & $S \& S C$ & R.S.A. & & & & $\mathbf{X}$ & & & & $\mathbf{X}$ & $\mathbf{X}$ & \\
\hline Dörgeloh et al. (1996) & $S \& S C$ & R.S.A. & $\mathbf{X}$ & & & & & & $\mathbf{X}$ & & & \\
\hline Heitkonig \& Owen-Smith (1998) & $\mathrm{S} \& \mathrm{SC}$ & R.S.A. & $\mathbf{X}$ & & & $\mathbf{X}$ & $\mathbf{X}$ & & & & & \\
\hline Dörgeloh (1998) & $\mathrm{S} \& \mathrm{SC}$ & R.S.A. & & & & $\mathbf{X}$ & & & & & & \\
\hline Dörgeloh et al. (1998) & $S \& S C$ & R.S.A. & & & & & $\mathbf{X}$ & & & & & \\
\hline Perrin \& Taolo (1998) & $S \& S C$ & R.S.A. & $\mathbf{X}$ & & $\mathbf{X}$ & & & $\mathbf{X}$ & & & & \\
\hline Harrington et al. (1999) & $\mathrm{S} \& \mathrm{SC}$ & R.S.A. & $\mathbf{X}$ & & & $\mathbf{X}$ & & & & $\mathbf{X}$ & $\mathbf{X}$ & \\
\hline Perrin \& Taolo (1999a) & $\mathrm{S} \& \mathrm{SC}$ & R.S.A. & $\mathbf{X}$ & & & $\mathbf{X}$ & & & & & & \\
\hline Perrin \& Taolo (1999b) & $S \& S C$ & R.S.A. & & & & & $\mathbf{X}$ & & & & & \\
\hline Dörgeloh (2001) & $\mathrm{S} \& \mathrm{SC}$ & R.S.A. & & & & $\mathbf{X}$ & & & & & & \\
\hline McLoughlin \& Owen-Smith (2003) & $\mathrm{S} \& \mathrm{SC}$ & R.S.A. & & & & & & & & & $\mathbf{X}$ & \\
\hline Martin (2003) & $S \& S C$ & Namibia & $\mathbf{X}$ & $\mathbf{X}$ & & $\mathbf{X}$ & $\mathbf{X}$ & & $\mathbf{X}$ & & $\mathbf{X}$ & \\
\hline M.E.T. (2003) & $S \& S C$ & Namibia & $\mathbf{X}$ & & & & & & & & $\mathbf{X}$ & $\mathbf{X}$ \\
\hline Kröger \& Rogers (2005) & $\mathrm{S} \& \mathrm{SC}$ & R.S.A. & & & & & & & & & $\mathbf{X}$ & \\
\hline Knoop \& Owen-Smith (2006) & $S \& S C$ & R.S.A. & $\mathbf{X}$ & & & $\mathbf{X}$ & $\mathbf{X}$ & & & & & \\
\hline Van Rooyen (2009) (Thesis) & $\mathrm{S} \& \mathrm{SC}$ & R.S.A. & & & & $\mathbf{X}$ & $\mathbf{X}$ & & & & & \\
\hline Havemann et al. (2014) & $\mathrm{S} \& \mathrm{SC}$ & Botswana & & & & & $\mathbf{X}$ & & & & & \\
\hline Havemann (2014) (Thesis) & $\mathrm{S} \& \mathrm{SC}$ & Botswana & $\mathbf{X}$ & & $\mathbf{X}$ & $\mathbf{X}$ & & & & $\mathbf{X}$ & & \\
\hline
\end{tabular}

Table 1 Published and unpublished studies pertaining to roan antelope ecology in Africa between 1960 and 2015. W = West Africa; N \& NE = North and North-East Africa; S \& $\mathrm{SC}=$ South and South-Central Africa; $\mathrm{X}=$ Aspects of roan antelope ecology that were included in the study: $\mathrm{D}=$ Declining. Abu. $=$ Abundance; Dist. $=$ Distribution; H.R. $=$ Home range; H.U. = Habitat use; Beh. = Behaviour; Pop. = Population; Dec. = Reason for decline; Econ. = Economic Value. 
2010). However, the results presented in many of these studies were presence or absence observations in a habitat type, recorded during abundance census efforts; they were not specific habitat utilization studies.

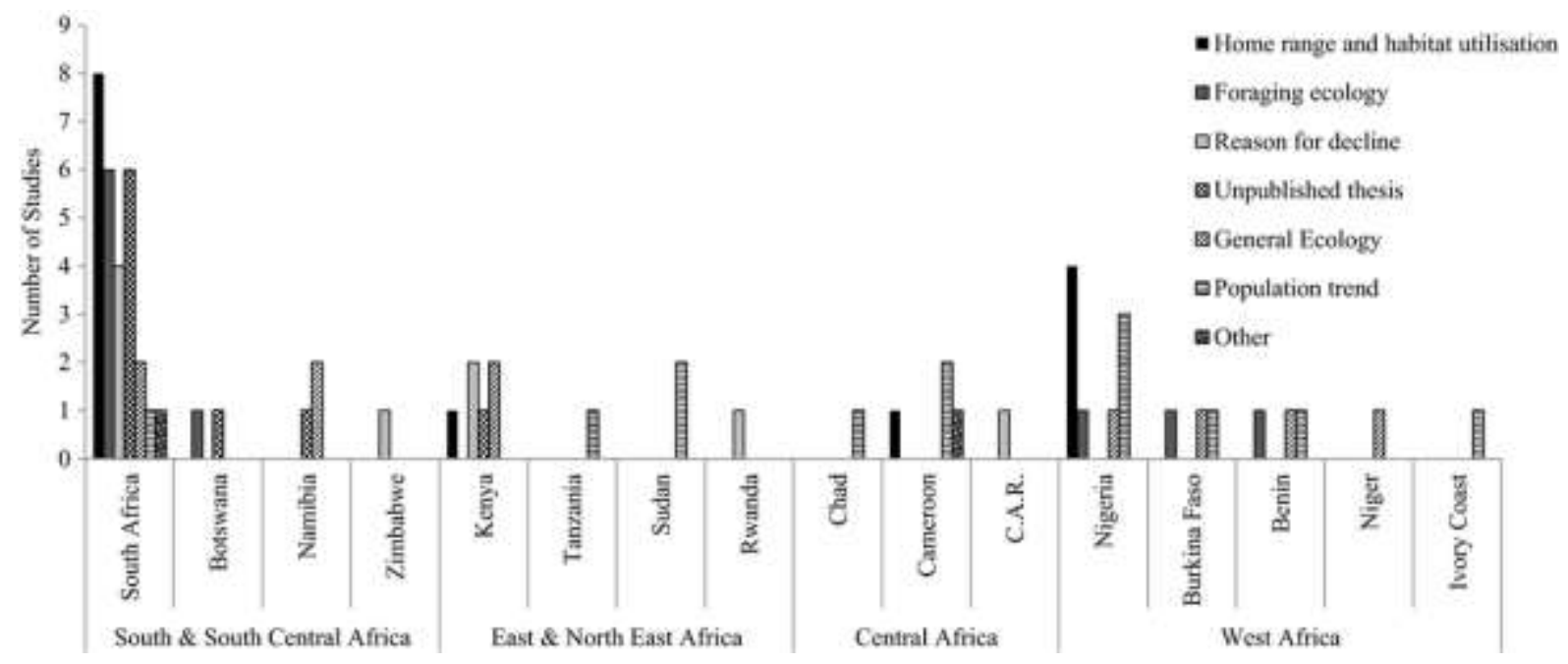

Figure 6 Numbers of ecological studies on roan antelope, their broadly categorized objectives, and the countries in which they were conducted, between 1960 and 2015. Total $\mathrm{N}=64$.

The widespread distribution of the roan antelope in Africa makes understanding habitat requirements and foraging ecology vital for conservation management (Dörgeloh 1998, Perrin \& Taolo 1999a). Home range use by roan antelope in Africa has been studied in South Africa (Joubert 1976, Perrin \& Taolo 1998), Kenya (Kimanzi 2011), Namibia (Erb 1993) and Botswana (Havemann 2014). Breeding herds tend to have home ranges that vary between 2 and $100 \mathrm{~km}^{2}$ in size; the distinct wet and dry season home ranges differ in grass species composition and topography. Roan antelope show a preference for certain parts of their home range, spending several days at a time within specific areas (Wilson \& Hirst 1977, Perrin \& Taolo 1998). Habitat use has been studied intensively in introduced roan antelope populations (Dörgeloh 1998, Perrin \& Taolo 1999a). Although these studies were of populations outside their natural range, the results provide important insights into how roan antelope adapt to new habitats.

Vegetation preference seems to be influenced by local conditions, including topography, vegetation type, water availability and the presence of competitors (Wilson \& Hirst 1977, Havemann 2014). Roan antelope are most abundant in moist or dystrophic savannas where soils are predominantly infertile (Heitkönig \& Owen-Smith 1998). They favour areas with few competitors or carnivores (Tyowua et al. 2012a, Havemann 2014). The need to avoid extrinsic pressures such as competition and predation may be facilitated by their ability to tolerate low-quality food and use plant parts not used by other ruminants (Heitkönig \& Owen-Smith 1998). A few researchers have identified roan antelope as highly selective feeders, with two or three grass species making up the bulk of their diet 
(Perrin \& Taolo 1999b, Martin 2003); other researchers have recorded 26 grass species and 19 species of woody plants in their diet (Martin 2003, Aremu 2004, Tyowua et al. 2013). Roan antelope appear to be capable of opportunistic feeding, by foraging on vegetation not commonly eaten by other large herbivores (e.g. Kigelia africana fruit; Havemann et al. 2014). Roan antelope are able to switch from being strict grazers ( $>95 \%$ grass) to mixed feeders $(<50 \%$ grass $)$ as the dry season progresses in Burkina Faso (Schuette et al. 1998). Roan antelope in Kenya (Andanje \& Ottichilo 1999) and South Africa (Heitkönig 1993) are mainly grazers; there is no significant increase in their intake of browse during any season. Roan antelope are more attracted to high-biomass foraging sites in the late wet and early dry seasons in South Africa; nutritional value is more important in the early wet and late dry seasons (Heitkönig and Owen-Smith 1998). Roan antelope are considered to be delicate feeders, utilizing the higher grass parts from 15 to $150 \mathrm{~cm}$ above ground (Martin 2003).

Generally, roan antelope prefer lightly wooded savanna with open areas of medium or tall grasses up to $1.5 \mathrm{~m}$, and avoid closed-canopy woodland and thick closed stands of bush $1.5 \mathrm{~m}$ to $4 \mathrm{~m}$ high (Joubert 1976, Perrin \& Taolo 1998, Schuette et al. 1998, Martin 2003, Tyowua et al. 2012a). They may also frequent dense woody vegetation (Gureja \& Owen-Smith 2002, Havemann 2014). Floodplain use appears to be important for this species throughout Africa, especially during summer, and may be attributed to the available high green leaf densities (Heitkönig \& Owen-Smith 1998, Havemann 2014) and forage with high sodium content. Roan antelope use 'dambo-like' grasslands and floodplains towards the end of the dry season in Cameroon (Tchamba \& Elkan 1995, Scholte et al. 2007), Nigeria (Afolayan \& Ajayi 1980), Tanzania (Caro 1999), Botswana (Havemann 2014) and South Africa (Knoop \& Owen-Smith 2006). Poor quality nutrition towards the end of the dry season caused by prolonged drought in rainfall-controlled ecosystems may cause nutritional stress in grazers such as sable and roan antelope (Macandza et al. 2014), but evidence for the nutritional stress hypothesis is limited (Codron et al. 2007). Alternatively, the maintenance of heterogeneous landscapes may be more important for roan antelope survival, and the loss of heterogeneity within a landscape may lead to an overall reduction in faecal nitrogen concentrations (Codron et al. 2009). Tall grass cover (to hide calves) and available surface water are essential for the survival of roan antelope, and herds are usually found less than 2 - 5 km from water (Wilson \& Hirst 1977, Grant et al. 2002, Martin 2003, Kimanzi 2011).

Roan antelope are likely to be sensitive to habitat changes caused by natural disturbance (e.g. by high numbers of elephants Loxodonta africana and other large mammal species) and anthropogenic disturbance (Martin 2003; Codron et al. 2009), due to their locally patchy distributions, fairly strict vegetation requirements, and feeding habits, although studies supporting this are required. Their ability to adapt to these disturbances may be limited by their mating systems and feeding strategies. They may be especially sensitive to changes in grass height and composition, as roan antelope rely on 
grass to camouflage their young and for foraging. Livestock and cattle expansion (occurring in many African countries) could pose a threat to roan antelope survival and reproductive success if not managed correctly (Matthys et al. 2010). Roan antelope cows typically occur in small harems, each with a dominant bull. Roan antelope cows leave the herd to calve in isolation. After giving birth, females leave their young to hide in tall grass during the day, and return to them after foraging. The calves remain hidden during the day and rely on effective camouflage and low body odour to avoid encounters with predators (Wilson \& Hirst 1977). They join the herd after 4-6 weeks, when they are strong enough to keep up with the herd's daily movements. Influxes of predators (both large and small) may increase mortality rates in altricial calves and isolated cows, as seen in the KNP (Harrington et al. 1999). Continuous pressure on reproductive success could result in an Allee effect caused by decreased individual fitness as a result of decreased herd vigilance due to small population size (Stephens \& Sutherland 1999, Owen-Smith et al. 2012).

\section{Conservation relevance and suggestions for management}

Despite being distributed throughout sub-Saharan Africa, roan antelope are found at low densities and in isolated populations. Distributional data are often disparate in terms of geographic and temporal coverage and, as a result, large data gaps exist. Alpers et al. (2004) currently provide the best support for roan antelope taxonomy in Africa. Only small numbers of specimens of Hippotragus equinus charicus and Hippotragus equinus bakeri were obtained, so future genetic studies should be focused on these subpopulations, to determine their taxonomic positions. Future regional conservation management plans referring to translocations of roan antelope populations should also follow the recommendations proposed by Alpers et al. (2004) to avoid cross breeding between evolutionary significant units.

Regional conservation efforts also depend on robust abundance estimates. Population estimates based on standardised techniques (with known bias and error estimates) for roan antelope are necessary for estimating population trends (Table 1). Future conservation efforts for roan antelope will require abundance estimates from throughout the entire geographical range of the species. The last in-depth study focussing on continental abundance was conducted more than 17 years ago (see East 1999; Figure 2). Many regions have not been surveyed at all, and data from those that have been surveyed indicate distinct regional differences in abundance estimates and consequent conservation status. Roan antelope have been counted using disparate methods ranging from foot surveys to aerial surveys (Tchamba \& Elkan 1995), resulting in population estimates that cannot be compared between populations. Roan antelope are currently classified as 'Least Concern' by the IUCN (Mallon \& Hoffmann 2008) due to insufficient data and a lack of evidence for declining population numbers. Abundance estimates of roan antelope exist for a few national parks, game reserves and privately owned lands in Africa. Many of these counts have occurred on isolated occasions or at irregular 
intervals, making population modelling ineffective. Roan antelope abundance has been estimated in 37 aerial surveys and 61 terrestrial surveys throughout Africa (1960-2012; Figures 3 and 4). Most studies were conducted before 2000 (Figure 3, Table 1) in only a few countries. Anecdotal information nonetheless suggests that populations are declining in most of Africa, as the roan antelope shifts from being a dominant savanna antelope species (before 1982; Milligan et al. 1982) to being rare in recent times. The lack of abundance data for the past decade is therefore particularly concerning. We can only speculate that roan numbers continue to decline. Aerial surveys are commonly used to count animals in inaccessible areas, but are unsuitable for counting roan antelope in South and South Central Africa where they occur in thick woodlands (Havemann 2014). Their light colour, low densities in many countries, small group sizes and the varying density of the vegetation they occur in (e.g. Fleming \& Tracey 2008) makes them difficult to count from the air. Roan antelope often remain motionless in thick vegetation, making them difficult to observe when a light aircraft flies over them. Careful consideration should thus be given to choosing the best surveying method or methods appropriate to local conditions. Unless reliable population estimates and data on local threats and environmental conditions are collected from all parts of the species' range, the reasons for any continued population declines will remain uncertain.

Roan antelope are ecologically similar to other rare ungulates such as sable antelope and tsessebe Damaliscus lunatus (e.g. Grant \& Van der Walt 2000, Grant et al. 2002, Martin 2003). These three species are all predominantly grazers and prefer open and wooded grassland savannas. They all have a patchy and discontinuous dispersion as a result of their known habitat requirements, and are similarly sensitive to disturbances and high (especially juvenile) predation rates (Grant \& Van der Walt 2000, Grant et al. 2002). These three species are also known to form stable herds in which one dominant male is associated with a fixed group of females including a dominant cow (Joubert 1974, Joubert \& Bronkhorst 1977). The importance of social structure in these species may have direct impacts on their mating success, as recruitment of new individuals into existing herds is dependent upon their acceptance by existing herd members (Joubert 1974, Joubert \& Bronkhorst 1977). In areas where herds are subject to high levels of predation, they may be unable to recruit new members or merge with other viable herds before being predated upon themselves.

Several different species distribution models exist that enable ecologists to predict extinction risk (Guisan \& Thuiller 2005, di Marco et al. 2014). These modelling techniques are reliant on environmental data from all parts of the species' range, and models include variables such as species' biology, disturbance indices, response to conservation intervention and habitat condition (e.g. di Marco et al. 2014). These models may prove to be of limited use in the case of a species such as roan antelope, a specialist grazer or browser adapting to a wide range of local habitats. The complex interaction between social interactions and resource availability, and the lack of regional data for roan 
antelope obfuscate the use of data-heavy modelling techniques. However, if roan antelope (or other similar rare ungulates such as sable antelope and tsessebe) can be used as a conservation model, determining ecological aspects and population trends of one species may provide insight into the extinction risks faced by the other species. Understanding the interactions between social structure, habitat preference and external pressures on these three species is thus vital for their effective conservation. Local governments and conservation bodies need to prioritize the conservation of rare antelope, and accordingly manage available habitats and predation and hunting pressure, in order to maintain effective social units (Caro et al. 2009).

The persistence of viable roan antelope populations may be an indication of stable ecosystems with little stochastic disturbance (Martin 2003). Their sensitive social structures may require long periods of time without disturbance or pressure in order to stabilise after losing herd members. In Southern Africa, where there is adequate protection, roan antelope are at the limit of their geographical range and are likely to represent refugee sub-populations (Grant et al. 2002, Cromsight et al. 2012). Given the current trend in human population growth in West Africa, Africa's roan antelope populations will remain threatened by poaching for bushmeat and habitat destruction (Brashares et al. 2004, Norris et al. 2010), and will continue to decline (East 1999). Conservation efforts in West Africa need to keep up with the human population boom, and need to pre-empt roan antelope population losses that will destabilise social units. Conservation areas need to be large enough to withstand external pressures due to increasing levels of isolation, and provide a buffer to increasing human populations at reserve

edges (Newmark 1998). The severe declines of roan antelope in the KNP in South Africa is an important case study for the other populations of the species that have not yet reached critically small population sizes, and illustrates the complexity of this species' habitat requirements and its sensitivity to predation pressure and disease. The effects of climate change add a complex dimension to ungulate conservation and persistence (Ogutu \& Owen-Smith 2003), one that cannot be investigated adequately without the existence of fundamental ecological data for the species. An uncertain and worrying picture emerges for the future of the second largest antelope in Africa, roan antelope, and when efforts are failing or none are even attempted for conservation of this charismatic species, it presents an ominous indicator of common challenges to several other large ungulates.

\section{ACKNOWLEDGEMENTS}

The University of Pretoria and South African National Research Foundation supported the authors during preparation of this literature review. We thank Valerio Macandza and an anonymous reviewer for their useful comments that improved this review. 


\section{REFERENCES}

Andanje SA, Ottichilo WK (1999) Population status and feeding habits of the translocated subpopulation of Hunter's antelope (Beatragus hunter, Sclater, 1889) in Tsavo East National Park, Kenya. African Journal of Ecology 37: 38-48.

Afolayan TA, Ajayi SS (1980) The influence of seasonality on the distribution of large mammals in the Yankari Game Reserve, Nigeria. African Journal of Ecology 18: 87-96.

Ajayi SS, Afolayan TA, Milligan KRN (1981) A survey of wildlife in Kwiambana Game Reserve, Nigeria. African Journal of Ecology 19: 295-298.

Allsopp R (1979) Roan antelope population in the Lambwe Valley, Kenya. Journal of Applied Ecology 16: 109-115.

Alpers DL, Van Vuuren BJ, Arctander P, Robinson TJ (2004) Population genetics of the roan antelope (Hippotragus equinus) with suggestions for conservation. Molecular Ecology 13: 1771-1784.

Anonymous (2003) Draft strategic species management plan for roan Hippotragus equinus, sable Hippotragus niger and tsessebe Damaliscus lunatus. Ministry of Environment and Tourism, Windhoek, Namibia.

Anonymous (2006) The IUCN Red List of Threatened Species. http://www.iucnredlist.org/

Anonymous (2012) Aerial census of animals in Botswana Dry Season 2012. Unpublished record, Research and Statistical Division, Department of Wildlife and National Parks, Gaborone, Botswana.

Anonymous (2015) World Population Prospects: The 2015 Revision, Key Findings and Advance Tables. Working Paper No. ESA/P/WP.241. United Nations, Department of Economic and Social Affairs, Population Division.

Ansell WFH (1971) 'Family Artiodactyla'. In: Meester J, Setzer HW (eds) The Mammals of Africa: an Identification Manual. Part 2, 1-84. Smithsonian Institution Press, Washington D.C., USA.

Aremu OT (2004) Density, distribution and feeding strategies of roan antelope (Hippotragus equinus) in Borgu sector of Kainji Lake National Park, Nigeria. Ghana Journal of Science 44: 39-45.

Barrie A (2009) Translocation of roan antelope in South Africa and the effect this has had on the genetic diversity of the species. Unpublished report, University of Johannesburg, Johannesburg, South Africa.

Beudels RC, Durant SM, Harwood J (1992) Assessing the risk of extinction for local populations of roan antelope Hippotragus equinus. Biological Conservation 61: 107-116.

Bezuidenhout R (2013) High value game farming: how to get started. Farmers Weekly Magazine, 15 July 2013. http://www.farmersweekly.co.za/article.aspx?id=41952\&h=High-value-gamefarming-\%E2\%80\%93-how-to-get-started . 
Brashares JS, Arcese P, Sam MK (2001) Human demography and reserve size predict wildlife extinction in West Africa. Proceedings of the Royal Society of London. Series B: Biological Sciences 268: 2473-2478.

Brashares JS, Arcese P, Sam MK, Coppolillo PB, Sinclair ARE, Balmford A (2004) Bushmeat hunting, wildlife declines, and fish supply in West Africa. Science 306: 1180-1182.

Bouché P, Renaud P-C, Lejeune P, Vermeulen C, Froment J-M, Bangara A, Fiongai O, Abdoulaye A, Abakar R, Fay M (2009) Has the final countdown to wildlife extinction in Northern Central African Republic begun? African Journal of Ecology 48: 994-1003.

Bouché P, Mange RNM, Tankalet F, Zowoya F, Lejeune P, Vermeulen C (2012) Game over! Wildlife collapse in northern Central African Republic. Environmental Monitoring Assessment 184: 7001-7011.

Caro TM (1999) Abundance and distribution of mammals in Katavi National Park, Tanzania. African Journal of Ecology 37: 305-313.

Caro TM, Young CR, Cauldwell AE, Brown DDE (2009) Animal breeding systems and big game hunting: models and application. Biological Conservation 142: 909-929.

Chase M (2011) Dry season fixed-wing aerial survey of elephants and wildife in northern Botswana. Elephants without Borders, San Diego Zoological Society, Department of Wildlife and National Parks. Report: 138.

Clegg SB, Turnbull PCB, Foggin CM, Lindeque PM (2007) Massive outbreak of anthrax in wildlife in the Malilangwe Wildlife Reserve, Zimbabwe. Veterinary Record 160: 113-118.

Codron D, Codron J, Lee-Thorp JA, Sponheimer M, Grant CC, Brink JS (2009) Stable isotope evidence for nutritional stress, competition, and loss of functional habitat as factors limiting recovery of rare antelope in southern Africa. Journal of Arid Environments 73: 449-457.

Craigie ID, Baillie JE, Balmford A, Carbone C, Collen B, Green RE, Hutton JM (2010) Large mammal population declines in Africa's protected areas. Biological Conservation 143: 22212228.

Cromsigt JPGM, Kerley GI H, Kowalczyk R (2012) The difficulty of using species distribution modelling for the conservation of refugee species - the example of European bison. Diversity and Distributions 18: 1253-1257.

di Marco M, Buchanan GM, Szantoi Z, Holmgren M, Marasini GG, Gross D, Tranquilli S, Boitani L, Rondinini C (2014) Drivers of extinction risk in African mammals: the interplay of distribution state, human pressure, conservation response and species biology. Philosophical Transactions of the Royal Society B: Biological Sciences 369: 20130198.

Djagoun CAMS, Codron D, Sealy J, Mensah GA, Sinsin B (2013) Stable carbon isotope analysis of the diets of West African bovids in Pendjari Biosphere Reserve, Northern Benin. South African Journal of Wildlife Research 43: 33-43. 
Dörgeloh WG (1998) Habitat selection of a roan antelope (Hippotragus equinus) population in Mixed Bushveld, Nylsvlei Nature Reserve. South African Journal of Wildlife Research. 28: 47-57.

Dörgeloh WG, Van Hoven W, Rethman NFG (1996) Population growth of roan antelope under different management systems. South African Journal of Wildlife Research 26: 113-116.

Dörgeloh WG, Van Hoven W, Rethman NFG (1998) Faecal analysis as an indicator of the nutritional status of the diet of roan antelope in South Africa. South African Journal of Wildlife Research 28: $16-21$.

Dörgeloh WG (2001) A draft habitat suitability model for roan antelope in the Nylsvley Nature Reserve, South Africa. African Journal of Ecology 39: 313-316.

du Toit JT \& Cumming DHM (1999) Functional significance of ungulate diversity in African savannas and the ecological implications of the spread of pastoralism. Biodiversity \& Conservation 8: 1643-1661.

East R (1999) African Antelope Database 1998 (Vol. 21). Gland, Switzerland; Cambridge, United Kingdom. (Online) URL: https://portals.iucn.org/library/efiles/edocs/ssc-op-021.pdf.

Erb KP (1993) The Roan antelope (Hippotragus equinus, Desmarest 1804), its ecology in the Waterberg Plateau Park. MSc thesis, University of Stellenbosch, Stellenbosch, South Africa.

Estes RD (1992) 'Horse Antelopes: Tribe Hippotragini' In: The behavior guide to African mammals, 115-122. Berkeley: University of California Press.

Fischer F, Linsenmair KE (2001) Decreases in ungulate population densities. Example from the Comoé National Park, Ivory Coast. Biological Conservation 101: 131-135.

Fischer F (2004) Status of the Comoé National Park, Côte d'Ivoire, and the effects of war. Parks 14: $17-25$.

Fleming PJS, Tracey JP (2008) Some human, aircraft and animal factors affecting aerial surveys: how to enumerate animals from the air. Wildlife Research 35: 258-267.

Foguekem D, Tchamba MN, Omondi P (2010) Aerial survey of elephants (Loxodonta africana africana), other large mammals and human activities in Waza National Park, Cameroon. African Journal of Environmental Science and Technology 4: 401-411.

Fynn RWS, Bonyongo MC (2011) Functional conservation areas and the future of Africa's wildlife. African Journal of Ecology 49: 175-188.

Geerling C, Bokdam J (1973) Fauna of the Comoé National Park, Ivory Coast. Biological Conservation 5: 251-257.

Gordon IJ, Hester AJ, Festa-Bianchet M (2004) Review: the management of wild large herbivores to meet economic, conservation and environmental objectives. Journal of Applied Ecology 41: 1021-1031.

Grant CC, Van der Walt JL (2000) Towards an adaptive management approach for the conservation of rare antelope in the Kruger National Park - outcome of a workshop held in May 2000. Koedoe 43: 103-112. 
Grant CC, Davidson T, Funston PJ, Pienaar DJ (2002) Challenges faced in the conservation of rare antelope: a case study on the northern basalt plains of the Kruger National Park. Koedoe 45: 45-66.

Guisan A, Thuiller W (2005) Predicting species distribution: offering more than simple habitat models. Ecology Letters 8: 993-1009.

Gureja N, Owen-Smith N (2002) Comparative use of burnt grassland by rare antelope species in a lowveld game ranch, South Africa. South African Journal of Wildlife Research 32: 31-38.

Hanks J (2001) Conservation strategies for Africa's large mammals. Reproduction, Fertility and Development 13: 459-468.

Harrington R, Owen-Smith N, Viljoen PC, Biggs HC, Mason DR, Funston PJ (1999) Establishing the causes of the roan antelope decline in the Kruger National Park, South Africa. Biological Conservation 90: 69-78.

Harris WC (1852) The sports of Southern Africa: being the narrative of a hunting expedition from the cape of Good Hope through the territories of the Chief Moselekatse, to the Tropic of Capricorn. HG Bohn, London, UK.

Havemann CP (2014) Population dynamics and foraging ecology of roan antelope in northern Botswana. MSc thesis, University of Pretoria, Pretoria, South Africa.

Havemann CP, Retief TA, Collins K, Fynn RWS, de Bruyn PJN (2014) First record of roan antelope (Hippotragus equinus) feeding on the fruits of the sausage tree (Kigelia africana). African Journal of Ecology 52: 568-570.

Heitkönig IMA (1993) Feeding strategies of roan antelope (Hippotragus equinus) in a low nutrient savanna. PhD thesis, University of Witwatersrand, Johannesburg, South Africa.

Heitkönig IMA, Owen-Smith N (1998) Seasonal selection of soil types and grass swards by roan antelope in a South African savanna. African Journal of Ecology 36: 57-70.

Joubert SCJ (1970) A study of the social behaviour of the roan antelope, Hippotragus equinus equinus (Desmarest, 1804), in the Kruger National Park. MSc thesis, University of Pretoria, Pretoria, South Africa.

Joubert SCJ (1974) The social organization of the roan antelope Hippotragus equinus and its influence on the spatial distribution of herds in the Kruger National Park. In: Giest V, Walther F (eds) The Behaviour of Ungulates and its Relation to Management, 661-675. IUCN, Morges, Switzerland.

Joubert SCJ (1976) The population ecology of the roan antelope, Hippotragus equinus equinus (Desmarest, 1804), in the Kruger National Park. DSc thesis, University of Pretoria, Pretoria, South Africa.

Joubert SCJ, Bronkhorst PJL (1977) Some aspects of the history and population ecology of the Tsessbe Damaliscus lunatus lunatus in the Kruger National Park. Koedoe 20: 125-145. 
Kimanzi JK (2011) Mapping and modelling the population and habitat of the roan antelope (Hippotragus equinus langheldi) in Ruma National Park, Kenya. PhD thesis, University of Newcastle, United Kingdom.

Kimanzi JK, Sanderson RA, Rushton SP (2014) Habitat suitability modelling and implications for management of roan antelopes in Kenya. African Journal of Ecology 52: 111-121.

Kimanzi JK, Sanderson RA, Rushton SP, Mugo MJ (2015) Spatial distribution of snares in Ruma National Park, Kenya, with implications for management of the roan antelope Hippotragus equinus langheldi and other wildlife. Oryx: 49: 295-302.

Kimanzi JK, Wanyingi JN (2014) The declining roan antelope population in Kenya: what is the way forward? Conference Papers in Science. 2014: doi:10.1155/2014/908628

Knoop M-C, Owen-Smith N (2006) Foraging ecology of roan antelope: key resources during critical periods. African Journal of Ecology 44: 228-236.

Kröger R, Rogers KH (2005) Roan (Hippotragus equinus) population decline in Kruger National Park, South Africa: influence of a wetland boundary. European Journal of Wildlife Research 51: $25-30$

Linard C, Gilbert M, Snow RW, Noor AM, Tatem AJ (2012) Population distribution, settlement patterns and accessibility across Africa in 2010. PLoS ONE, 7:e31743 doi:10.1371/journal.pone.0031743

Lopes AA (2015) Organized crimes against nature: elephants in Southern Africa. Natural Resource Modeling 28: 86-107.

Macandza V, Owen-Smith N, Roux E (2014) Faecal nutritional indicators in relation to the comparative population performance of sable antelope and other grazers. African Journal of Ecology 52: 300-307.

Mallon DP, Hoffmann M (2008) Roan assessment, IUCN SSC Antelope Specialist Group. The IUCN Red List of Threatened Species. http://www.iucnredlist.org/details/10167/0.

Marchal A, Lejeune P, Bouché P, Ouédraogo M, Sawadogo P, Yaméogo D-D, Yanogo F, Vermeulen C (2012) Status of medium-sized ungulate populations in 2010, at the Nazinga Game Ranch, Burkino Faso (Western Africa). Biotechnology, Agronomy, Society and Environment 16: 307315.

Martin RB (2003) Species report for roan Hippotragus equinus, sable Hippotragus niger and tsessebe Damaliscus lunatus.Ministry of Environment and Tourism, Windhoek, Namibia. URL: http://www.rarespecies.org.na/library/speciesreports.htm.

Martin A, Caro T (2012) Illegal hunting in the Katavi-Rukwa ecosystem. African Journal of Ecology 51: $172-175$.

Matthee CA, Robinson TJ (1999) Mitochondrial DNA population structure of roan and sable antelope: implications for the translocation and conservation of the species. Molecular Ecology 8: 227-238. 
Matthys PC, Lehutso BJ, Fynn RWS, Murry-Hudson M (2010) Analysis of population distribution of sable (Hippotragus niger) and roan (Hippotragus equinus) antelope in northern Botswana. Unpublished report, Okavango Research Institute, University of Botswana, Maun, Botswana.

McLoughlin CA, Owen-Smith N (2003) Viability of a diminishing roan antelope population: predation is the threat. Animal Conservation 6: 231-236.

Milligan K, Ajayi SS, Hall JB (1982) Density and biomass of the large herbivore community in Kainji Lake National Park, Nigeria. African Journal of Ecology 20: 1-12.

Mohammed I, Shehu AI, Adamu MB, Saleh UF (2010) Comparative analysis of fauna numerical characteristic of Yankari Game Reserve from 1980-2008. Environmental Research Journal 4: 177-181.

Newmark WD (2008) Isolation of African protected areas. Frontiers in Ecology and the Environment 6: 321-328.

Norris K, Asase A, Collen B, Gockowksi J, Mason J, Phalan B, Wade A (2010) Biodiversity in a forest-agriculture mosaic - The changing face of West African rainforests. Biological Conservation 143: 2341-2350.

Ogutu JO, Owen-Smith N (2003) ENSO, rainfall and temperature influences on extreme population declines among African savanna ungulates. Ecology Letters 6: 412-419.

Omondi P, Mayienda R, Mshelbwala JH, Massalatchi MS (2006) Total aerial count of elephants, buffaloes, roan antelope and other wildlife species in Yankari Ecosystem, Nigeria. For CITES $M I K E$ program, $E U$. https://cites.org/common/prog/mike/survey/0607_FW_AT_Survey_Yankari.pdf

Owen-Smith N, Chirima GJ, Macandza V, Le Roux E (2012) Shrinking sable antelope numbers in Kruger National Park: what is suppressing population recovery? Animal Conservation 15: 195-204.

Perrin MR, Taolo C (1998) Home range, activity pattern and social structure of an introduced herd of roan antelope in KwaZulu-Natal, South Africa. South African Journal of Wildlife Research 28: $27-32$.

Perrin MR, Taolo C (1999a) Habitat use by a herd of introduced roan antelope in KwaZulu-Natal, South Africa. South African Journal of Wildlife Research 29: 81-88.

Perrin MR, Taolo CL (1999b) Diet of introduced roan antelope at Weenen Nature Reserve, South Africa. South African Journal of Wildlife Research 29: 43-51.

Poché RM (1974) Notes on the roan antelope (Hippotragus equinus (Desmarest)) in West Africa. Journal of Applied Ecology 11: 963-968.

Scholte P, Adam S, Serge BK (2007) Population trends of antelopes in Waza National Park (Cameroon) from 1960 to 2001: the interacting effects of rainfall, flooding and human interventions. African Journal of Ecology 45: 431-439. 
Schuette JR, Leslie $J_{R}$ DM, Lochmiller RL, Jenks JA (1998) Diets of hartebeest and roan antelope in Burkina Faso: Support of the long-faced hypothesis. Journal of Mammalogy 79: 426-436.

Sekulic R (1978) Note on interactions between Sable (Hippotragus niger) and Roan (Hippotragus equinus) antelopes in Kenya. Journal of Mammalogy 59: 444-446.

Sinsin B, Tehou AC, Daouda I, Saidou A (2002) Abundance and species richness of larger mammals in Pendjari National Park in Benin. Mammalia 66: 369-380.

Skinner JD, Smithers RHN (eds; 1990) The mammals of the southern African subregion. University of Pretoria, Pretoria, South Africa.

Stark MA (1986) The numbers, seasonal distribution patterns, densities and biomass of the large herbivores, Benoue National Park, Cameroon. Mammalia 50: 341-350.

Stephenson A (2013) Aerial Wildlife Census Parque Nacionale do Limpopo 2013. Unpublished report

Stoner C, Caro T, Mduma S, Mlingwa C, Sabuni G, Borner M, Schelten C (2006) Changes in large herbivore populations across large areas of Tanzania. African Journal of Ecology 45: 202215.

Stoner C, Caro T, Mduma S, Mlingwa C, Sabuni G, Borner M (2007) Assessment of effectiveness of protection strategies in Tanzania based on a decade of survey data for large herbivores. Conservation Biology 21: 635-646.

Tchamba MN, Elkan P (1995) Status and trends of some large mammals and ostriches in Waza National Park, Cameroon. African Journal of Ecology 33: 366-376.

Thuiller W, Broennimann O, Hughes G, Alkemade JRM, Midgley GF, Corsi F (2006) Vulnerability of African mammals to anthropogenic climate change under conservative land transformation assumptions. Global Change Biology 12: 424-440.

Tyowua BT, Agbelusi EA, Ogunjemite BG (2010) The common woody plants in roan antelope (Hippotragus equinus, Desmarest.1804) habitat in Kainji Lake Natural Park, Nigeria. African Journal of Ecology 48: 269- 271.

Tyowua BT, Orsar JT, Agbelusi EA (2012a) Habitat preference of roan antelope (Hippotragus equinus, Desmarest.1804) in Kainji Lake National Park, Nigeria. International Research Journal of Agricultural Science and Soil Science 2: 421-425.

Tyowua BT, Agbelusi EA, Oyeleke OO (2012b) Evaluation of roan antelope habitats (Hippotragus equinus, Desmarest.1804) in Kainji Lake National Park, Nigeria. Global Advanced Research Journal of Environmental Science and Toxicology 1: 166-171.

Tyowua BT, Orsar JT, Agbelusi EA (2012c) Seasonal variation in herd size of roan antelope (Hippotragus equinus, Desmarest 1804) in Kainji Lake National Park, Nigeria. Global Advanced Research Journal of Environmental Science and Toxicology 1: 110-114.

Tyowua BT, Agbelusi EA, Orsar JT (2013) Roan antelope (Hippotragus equinus, Desmarest 1804) food plants and feeding habits in Kainji Lake National Park, Nigeria. Journal of Research in Forestry, Wildlife and Environment 4: 22-29. 
Van Lavieren LP, Esser JD (1979) Numbers, distribution and habitat preference of large mammals in Bouba Ndjida National Park, Cameroon. African Journal of Ecology 17: 141-153.

Van Rooyen R (2009) Habitat and Seasonal effects on the nutrient status of selected roan Hippotragus equinus, and Sable antelope Hippotragus niger populations in South Africa. MSc thesis, University of Pretoria, Pretoria, South Africa.

Van Wilgen BW, Biggs HC (2011) A critical assessment of adaptive ecosystem management in a large savanna protected area in South Africa. Biological Conservation 144: 1179-1187.

Waller DM, Alverson WS (1997) The white-tailed deer: a keystone herbivore. Wildlife Society Bulletin 25: 217-226.

Waltert M, Meyer B, Kiffner C (2009) Habitat availability, hunting or poaching: what affects distribution and density of large mammals in western Tanzanian woodlands? African Journal of Ecology 47: 737-746.

Wilson DE (1975) Factors affecting roan and sable populations on nature reserves in the Transvaal with particular reference to ecophysiological aspects. DSc thesis, University of Pretoria, Pretoria, South Africa.

Wilson DE, Hirst SM (1977) Ecology and factors limiting roan and sable antelope populations in South Africa. Wildlife Monographs 54: 3-111.

Wittemyer G, Elsen P, Bean WT, Burton ACO, Brashares JS (2008) Accelerated human population growth at protected area edges. Science 321: 123-126. 